\title{
論理構造の構造化演習と分節化演習の演習順序による演習難 易度の差 \\ Difference in Task Difficulty Level Based on Task Order of Structuring Task of Logic Structure and Segmentation Task
}

\author{
北村 拓也広島大学大学院工学研究科 \\ Takuya Kitamura Graduate School of Engineering, Hiroshima University \\ kitamura@lel.hiroshima-u.ac.jp, http://hiroshima-u.jp/eng \\ 平嶋 宗 \\ (同上) \\ Tsukasa Hirashima \\ tsukasa@lel.hiroshima-u.ac.jp, http://hiroshima-u.jp/eng
}

Keywords: logical thinking, triangle logic model, logic structure

\section{Summary}

Regarding cultivation of the capacity to think logically, we designed/developed system that enables segmentation task and measured time change and learning effect by application order using structuring task system developed in the existing study. Subjects were 14 university students/graduate students. In order to verify the difference of task difficulty by exercise working order, we analysed exercise time. As a result, the structuring task first group showed significant decrease of segmentation task exercise time compared to that of the segmentation first group.

\section{1. はじめに}

論理的思考力[文化庁 04 , 文部科学省]の育成は近年特 に重要視されるようになってきている.しかしながら, 論理的思考力をどのように育成するかについて明確な答 えは出ていない. 著者らは先行研究において, 論理的思 考力の育成に対し，オープン情報構造アプローチ[平嶋 18a]を適用することによる学習効果を確認した[北村 17]. 具体的には, 論理の構造を情報構造として具体化し, 学習者がインタラクティブに操作活動を行える環境を設 計・開発し, その活動に効果があることを実験的に検証し た.

オープン情報構造アプローチは, 思考を情報構造に対 する操作とする仮説に基づいている[平嶋 15]. 情報構造 とは，思考の対象を構成要素と構成要素間の関係として 記述したものである. そして, 情報構造に対する操作は 2 種類に分けられる. 思考の対象から情報構造を取り出 す「分節化操作」と, 取り出された情報構造を操作する 「構造化操作」である [平嶋 $18 \mathrm{~b}$ ] .

先行研究[北村 17]では, 既に分節化された部品を提供 することで, 学習者は構造化操作だけを行うシステムを 実装し, その有効性を検証した。 なぜなら, 分節化操作 は新たなプリミティブを自分で定義することと考えると， 学習者に新規性のある知を生み出すことを期待すること になり，極めて困難なタスクであるからである[平嶋
$18 b]$.

しかしながら，順序的には分節化操作を先に行うこと が，対象の理解において重要であるとも考えられる．人 が文章を読み，その文章の情報構造を理解する時，文章 から情報構造を取り出す(分節化操作)を行い, 取り出し た情報構造を操作する(構造化操作)という順序で行うた めである.

著者らは分節化操作の重要性を認めつつも, 構造化操 作を先に行うことが妥当であると考えている．この仮説 は, 分節化操作の目的が構造化操作であり, 構造化操作 を先に行うことで, 構造化操作が分節化操作に対する先 行オーガナイザー[Ausubel 60]として機能すると考える からである。

この仮説を検証するために, 本研究では分節化操作を 可能にするシステムを設計・開発し，先行研究で開発し た構造化操作のシステムを用いて，使用順序による時間 の変化と学習効果を計測した，第 2 章では，実験で用い た構造化操作と分節化操作のシステムについて説明する. 第 3 章で実験とその結果について述べ，第 4 章でまとめ を述心゙る。なお，学習者がシステム内で構造化操作，分 節化操作を行う演習をそれぞれ構造化演習, 分節化演習 と表現する. 


\section{2. システム}

本章では，論理の三角ロジックモデルと三角ロジック を対象とした構造化演習システム[北村 17], および本研 究で開発した分節化・構造化演習システムについて述心 る.

\section{$2 \cdot 1$ 三角ロジックモデルと構造化演習}

論理において，モーダスポネンス $((\mathrm{P} \rightarrow \mathrm{Q}) \wedge \mathrm{P}) \vdash \mathrm{Q}$,およ び三段論法 $((\mathrm{P} \rightarrow \mathrm{Q}) \wedge(\mathrm{Q} \rightarrow \mathrm{R})) \vdash \mathrm{R}$ は, 三つの命題により 成立している。 三角ロジックモデルは，この三つの命題 を根拠, 理由付け, 主張として,三角形の各頂点に配置し, それぞれの要素を他の要素と結んだ構造的表現である. 図 1 にその例を示した. 図 1 における各辺の推論は, 各 辺の両端の命題が与えられた場合に対頂点の命題を推論 することを表している.

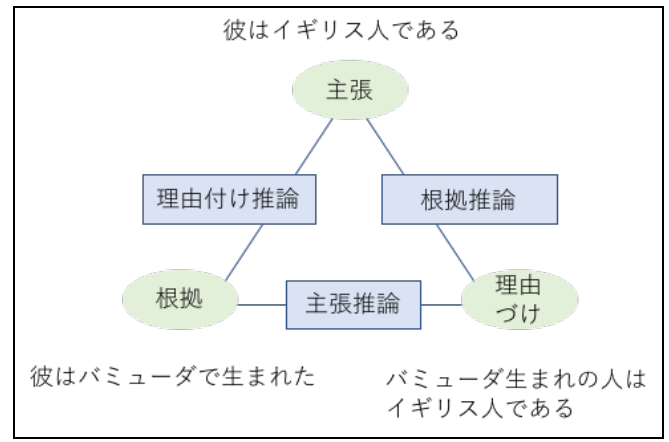

図 1 三角ロジックモデル

構造化演習では，（1）提供された部品を使って三角口 ジックを組み立てる演習(組み立て演習),（2）提供され た部品を使って複数の三角ロジックを組み立てる演習 (複数組み立て演習), の二つの演習を実装した. 組み立て 演習はさらに，(1-1)二つの命題が配置された三角ロジッ クと残りの一つの命題の候補集合を提供し，残りの一つ の命題を選択・配置する演習，(1-2）一つの命題が配置さ れた三角ロジックと残りの二つの命題の候補集合を提供 し, 残りの二つの命題を選択・配置する演習, (1-3) 命題 が配置されていない三角ロジックと三つの命題の候補集 合を提供し, 適切な命題を選択・配置する演習を実装して いる.

図 2 に, 組み立て演習(二つの命題が配置)のシステム 画面を示した。学習者は, システムから提供された複数 の命題（Cards と記された場所に提供されている）から 取捨選択を行って，三角形の頂点に配する．システムは 作成された三角ロジックを診断し，即時的に診断結果を フィードバックし(間違えた箇所が赤くなる), 間違いの 場合は学習者に修正を促す。複数組み立て演習の画面を 図 3 に示した。

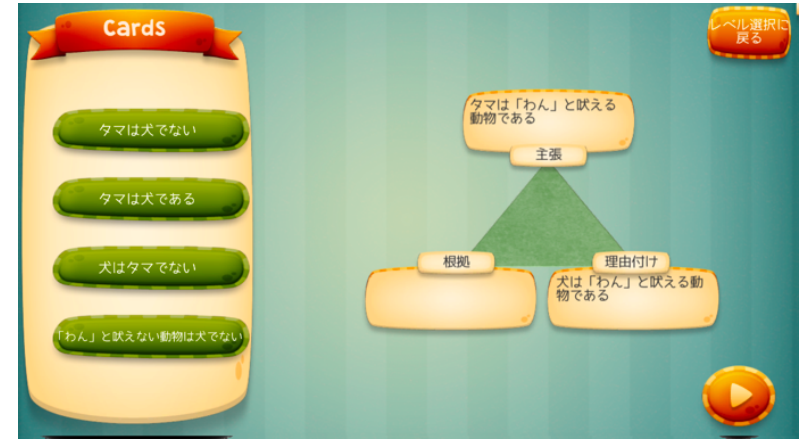

図 2 組み立て演習画面 : 二つの命題が配置されている

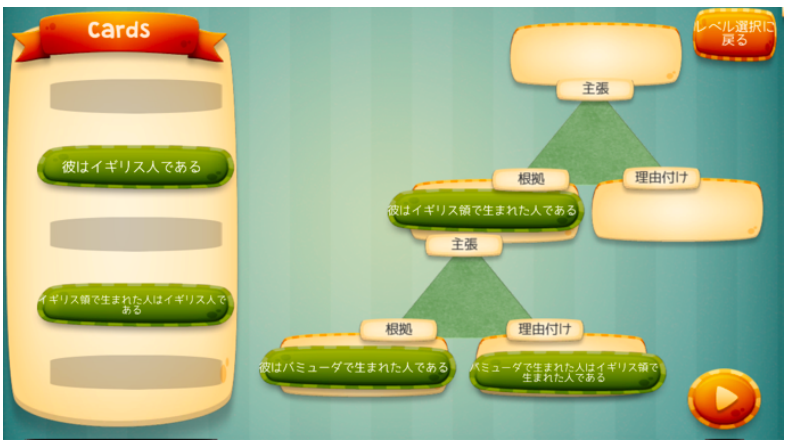

図 3 複数組み立て演習のシステム画面

\section{$2 \cdot 2$ 分節化·構造化演習システム}

分節化操作とは，論理を構成する命題を取り出すこと であり，本研究では，自然言語文から三角ロジックを構 成する部品としての命題を取り出すことであるとする. 分節化操作はそれだけでは意味を持たないため，分節化 操作によって取り出された命題を構造化操作する部分も 行う必要があると考え, まず自然言語文から命題を取り 出す作業として分節化演習を行い，さらに取り出した命 題を三角ロジックに当てはめる作業を行う.

分節化演習の画面を図 4 に示す。学習者のフローを述 べる，学習者は画面左側の文章を読み，指示された主張 を組み立てるための三つの命題を抜き出す。この際，学 習者は自分の考えた命題を自由記述で入力する. システ ムにはあらかじめ候補となりうる命題が用意されており， 学習者の入力との類似度を取り，類似度の高い候補をい くつか学習者に提示する。学習者はその中から意図した 命題を選択する．本システムでは，命題候補はレーベン シュタイン距離と N-gram を用いて, 学習者の入力と類 似度が高い命題上位三つを選出し，候補として表示して いる．選択可能な命題が提示されない場合は，学習者の 自由記述での命題表現の変更を求めることになる。この 作業を三つの命題を作るまで繰り返す，学習者が取り出 し可能な命題としては，正解となる論理を構成する命題 （正しい命題）に加えて，正しい命題の構成要素を組み 合わせて作られたダミーの命題（ダミー命題）が用意さ れている，学習者がダミー命題を選択した場合でも，シ ステムは正誤のフィードバックを行わない，これは，学 
習者がそのフィードバックを手掛かりに，命題を吟味せ ずに選択することを避けるためである. 正誤のフィード バックは論理が組み立てられた後に行われるため, 学習 者は論理の組み合わせの問題か, その論理を構成する命 題の問題であるかは, 自身で吟味することが求められる.

三つの命題を作り終わった学習者は, 構造化に進む. 作成した命題に対しての構造化演習は 2.1で説明した図 2 の内容と同様である. 構造化演習で間違えたときのシ ステム画面を図 5 に示した。

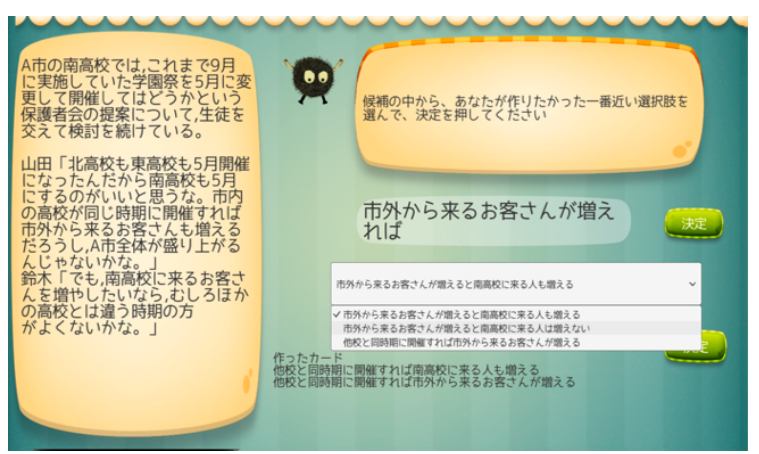

図 4 分節化演習のシステム画面

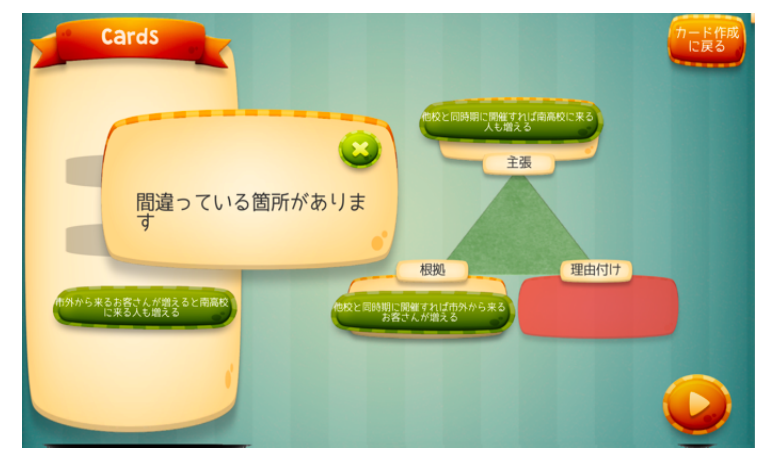

図 5 構造化演習画面で間違えたときのシステム画面

\section{3. 実験}

\section{$3 \cdot 1$ 実験概要}

本実験は, 本演習が(i) 学習者の論理的思考力育成に効 果があるか (以下, 学習効果と呼ぶ), (ii)分節化・構造化 演習と構造化演習を行う順序で, 演習の難易度に差があ るか，を調べるために行った，学習効果については，プ レテストとポストテストにおけるスコアの差を比較する ことで評価した，演習の難易度の差については演習を終 えるのに要した時間 (以下, 演習時間と呼ぶ), を用いて 評価した. なお, 本演習では正解となる論理構造を組み 立てることができて初めて次の課題に進めるようになっ ている.

\section{$3 \cdot 2$ 実験手順}

被験者は情報工学系の大学生·大学院生 14 名である. 被験者の内訳は, 構造化演習を先に行う構造化先群 7 名 と, 分節化・構造化演習を先に行う分節化先群 7 名であ る. 構造化先群における手順は, (1)プレテスト, (2)構造
化演習および分節化・構造化演習 (プレテストの 7 日後), (3)演習の直後のポストテスト, となっている. 分節化先 群は, 上記手順(2)において, 分節化・構造化演習を先に 行い, 次に構造化演習を行った。

プレテストおよびポストテストには, 国立教育政策研 究所教育課程研究センターが高校生を対象に論理的に思 考する力の育成状況に着目して実施した「特定の課題に 関する調查（論理的な思考）」で用いられた問題のうち,

「一般的な表現形式による問題」（22 問）を用いた[国立 教育政策研究所 17]. 回答時間は 45 分, 44 点満点に設 定した. 先行研究 [北村 17] (回答時間 40 分, 22 点満点) と異なるのは，より正確に調査するためである.

分節化・構造化演習には 1 問の課題を実装した。構造 化演習には，30 問の課題を実装した。問題数は, 両演習 合わせて 30 分以内程度に演習時間を短くするために調 整した。

\section{3 実験結果と分析}

\section{$\S 1$ 結果分析の方法}

演習の学習効果は, プレテストとポストテストの差を 構造化先群と分節化先群とで比較することで確認した。 また, 演習取り組夕順序による課題難易度の違いを確認 するために，演習時間の分析を行った。

\section{§ 2 テストスコアの分析}

プレテストおよびポストテストの結果を示す. 構造化 先群における，プレテストの結果は 30.571(SD : 5.386) 分, ポストテストの結果は 35.571(SD : 2.871)分であっ た.また, 分節化先群における, プレテストの結果は 30.429(SD：3.736) 分, ポストテストの結果は 36.571(SD : 1.761)分であった. 演習の取り組み順序の違 いを被験者間要因,テストのプレ・ポストを被験者内要因 としてANOVA4 を用いた 2 要因分散分析を行ったとこ 万，交互作用は有意差は無かった $(\mathrm{p}=0.6838>0.5)$. 下位 検定（ANOVA4 に組み込まれた Rayn 法を用いた）を行 ったところ単純主効果として，プレテストにおいて構造 化先群と分節化先群の有意差はなく $(\mathrm{p}=0.947>0.05)$, ポ ストテストにおいても有意差はなかった $(p=0.641>0.05)$.また, 構造化先群においてプレテスト とポストテストにおいて有意差があった $(p=0.024<.05)$. 分節化先群においてもプレテストとポストテストにおい て有意差があった（ $\mathrm{p}=0.008<0.05 ）$.

\section{$\S 3$ 演習時間の分析}

構造化演習および分節化・構造化演習を終えるのに要 した時間を表 1 に示す. 構造化先群における, 構造化演 習時間は 13.571(SD : 4.594)分, 分節化・構造化演習時 間は 5.714(SD : 2.05)分であった. また, 分節化先群に おける, 構造化演習時間は $12.571(\mathrm{SD}: 4.924)$ 分, 分節化・ 構造化演習時間は $14.0(\mathrm{SD}: 4.66)$ 分であった. 演習の取 
り組み順序の違いを被験者間要因, 構造化演習時間と分 節化・構造化演習時間を被験者内要因としてANOVA4を 用いた 2 要因分散分析を行ったところ, 交互作用は有意 であった $(\mathrm{p}=0.0256<.05)$. 下位検定を行ったところ単純 主効果として, 構造化演習時間において構造化先群と分 節化先群の有意差はなく $(\mathrm{p}=0.6852>.05)$, 分節化・構造 化演習時間において有意差があった（ $\mathrm{p}=0.0024<.01 ）$.

\begin{tabular}{|c|c|c|}
\hline & 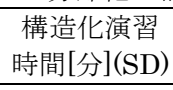 & $\begin{array}{l}\text { 分節化・構造化 } \\
\text { 演習時間[分](SD) }\end{array}$ \\
\hline $\begin{array}{c}\text { 構造化先 } \\
\text { 群 } \\
(\mathrm{n}=7)\end{array}$ & $\begin{array}{l}13.571 \\
(4.594)\end{array}$ & $\begin{array}{l}5.714 \\
(2.05)\end{array}$ \\
\hline $\begin{array}{c}\text { 分節化先 } \\
\text { 群 } \\
(n=7)\end{array}$ & $\begin{array}{l}12.571 \\
(4.924)\end{array}$ & $\begin{array}{l}14.0 \\
(4.66)\end{array}$ \\
\hline$p$ 值 & $0.6852>0.05$ & $0.0024<0.01$ \\
\hline
\end{tabular}

\section{$3 \cdot 4$ 実験結果に対する考察}

テストスコアについては, 両群ともに有意な学習効果 が見られ，また両群に差が見られなかったことから，演 習順序による学習効果の影響は見られなかった。ただし 本研究での学習効果には, 得点の上昇に関してテストの 慣れがあったのではないかとも考えられる. そのため, 先行研究 [北村 17] での三角ロジックの演習効果を示す ために用いた統制群のデータ (44 点満点で採点) と比較し たところ, 三群(構造化演習先群, 分節化演習先群, 統制 群)の分散分析で, 交互作用がでて（有意傾向 $\mathrm{p}=0.0611 ）$, 演習をした群だけ成績向上が見られたことから，演習の 効果があったことが確認できた(構造化先群 $\mathrm{p}=0.0029$, 分節化先群 $\mathrm{p}=0.0004$, 統制群 $\mathrm{p}=0.6648)$. 統制群は, 本 研究で用いたプレテスト・ポストテストと同内容のテス 卜を 1 週間の間隔をあけて 2 回解いた群（大学生・大学 院生 16 名）である.

演習に要した時間に関しては, 構造化先群において, あとの演習である分節化・構造化演習の時間が，分節化 先群の分節化・構造化演習の時間よりも大幅に短縮され ている.これは, 構造化演習を行うことが, 分節化・構 造化演習の遂行を容易にしていることを示している。こ れは当初の仮説どおり, 構造化演習が先行オーガナイザ 一として機能したと考えられる．なぜなら，分節化の練 習を行っていないにもかかわらず，分節化・構造化演習 の解決速度が上がっていることを示唆する結果（分節化 演習先群との比較において) が得られているからである. 構造化演習により情報構造を理解した学習者は, 分節化 において切り出す構造の部品に対する理解が促進された
と考えられる。本研究では小規模の実験ではあるが，人 の学習支援において, 分節化・構造化演習よりも構造化 演習を先に行う重要性を示す傍証になったと考えられる。

\section{4. まとめ}

分節化演習の仕組みを実装した上で, 実験により構造 化演習と分節化演習を行う順序が, 課題の難易度に及ぼ す影響について確認した。今回は演習問題数・被験者数 共に小規模な実験であったが，構造化演習の重要性に関 して重要な示唆が得られたと考えている. 今後, 分節化 演習の問題数を増やし, 被験者を増やした大規模な実験 にも取り組む予定である.

\section{参考文献 $\diamond$}

[Ausubel 60] Ausubel,D P : The use of advance organizers in the learning and retention of meaningful verbal material ,Jounal of Educational Psychology,Vol.51,pp.267-272(1960).

[文化庁 04] 文化庁：「これからの時代に求められる国語力につ いて」文化審議会答申 (2004).

[文部科学省]文部科学省:国語力を身に付けるための国語教育の 在り方, http://www.mext.go.jp/b_menu/shingi/bunka/toushin/0 4020301/007.htm(閲覽日:2019 年 4 月 11 日).

[平嶋 15] 平嶋宗：「学習課題」中心の学習研究 一情報構造 としての学習課題の再定義と構造操作としての学習活動 の設計一，人工知能学会誌,Vol.30,No.3,pp.277280(2015).

[平嶋 18a] 平嶋宗, 林雄介 : メ夕問題設計法としてのオープン 情報構造アプローチ, 人工知能学会研究会資料,SIGALST-B509(2018)

[平嶋 18b] 平嶋宗 : ディープアクティブ・ラーニングを指向 した課題設計法としてのオープン情報構造アプローチ： 外在タスク・メ夕問題・仮説検証的試行錯誤, The 32nd Annual Conference of the Japanese Society for Artificial Intelligence(2018).

[北村 17] 北村拓也,長谷浩也,前田一誠,林雄介,平嶋宗 : 論理構 造の組み立て演習環境の設計開発と実験的評価,人工知能 学会論文誌 Vol.32,No.6 C-H14_1-12(2017).

[国立教育政策研究所 17] 特定の課題に関する調查（論理的な 思考）,http://www.nier.go.jp/kaihatsu/tokutei_ronri/(閲 覽日:2019 年 4 月 11 日).

[担当委員 : 長谷川 忍]

2018 年 7 月 13 日 受理 


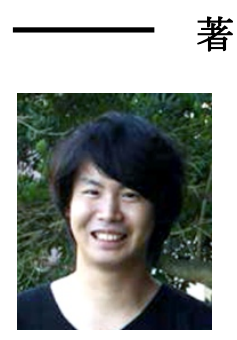

\section{著 者 紹 介}

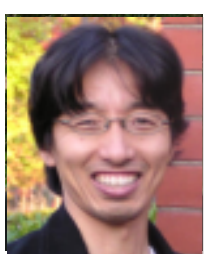

北村 拓也（学生会員）

2016年広島大学工学部第二類情報工学課程 卒業. 2017 年同大学院工学研究科博士課程 前期修了. 現在, 同課程後期に所属. 2016 年度本学会研究会優秀賞受賞.

平嶋 宗 (正会員)

1986 年大阪大学工学部応用物理学科卒業, 1991 年同大学院工学研究科博士課程修了. 同年, 大阪大学産業科学研究所助手, 同講 師, 九州工業大学情報工学部助教授を経て, 2004 年より広島大学大学院工学研究科教授. 人間を系に含んだ計算機システムの高度化, 特に学習工学に関寸る研究に従事. 工学博 士. 